\author{
${ }^{1}$ Гудз Г. С., ${ }^{1}$ Глобчак М. В, ${ }^{1}$ Коцюмбас О. Й., ${ }^{2}$ Захара І. Я. \\ ${ }^{1}$ Національний університет «Львівська політехніка» м. Львів \\ ${ }^{2}$ Івано-Франківський національний технічний університет нафти і газу
}

\title{
ПОРІВНЯЛЬНА ОЦІНКА АЛГОРИТМІВ ДЕМОНТАЖУ ПНЕВМОПІДВІСКИ АВТОБУСА БАЗ А 11110 НА ЗАСАДАХ СТРУКТУРНОГОАНАЛІЗУ
}

\begin{abstract}
У статті описані конструктивні особливості пневмопідвісок керованих та ведучих коліс автобуса А 11110 з метою їхнього структурного аналізу при проведенні розбиральних робіт. Для цього залучений метод теорії графів, який виявляє орієнтовані зв'язки між елементами підвіски.

Побудовані для них графи доступу для трьох варіантів розбиральних робіт. Кількісний аналіз функцій доступу виявив найбільш раціональний варіант. Такий метод можна застосувати для оптимізації розбиральних робіт інших агрегатів (вузлів) автотранспортних засобів.

Ключові слова: пневмопідвіска, автобус, ремонтоздатність, графи та функції доступу.
\end{abstract}

Постановка проблеми. Розбиральні роботи є найбільш трудомісткими й складають $10,8 \%$ від загальної трудомісткості ремонту автобуса [1] й повинні проводитись у певній послідовності із застосуванням необхідного обладнання, пристроїв та інструменту. Раціональну послідовність технологічного процесу можна скласти за допомогою структурної оцінки ремонтоздатності складаних одиниць автомобіля з позицій пошуку полегшеного доступу до невідновлюваних деталей за відмов агрегатів або вузлів [2]. Тому доступ стає важливим чинником, що визначає ремонтоздатність пневматичних підвісок автобусів під час розбиральних операцій.

Аналіз останніх досліджень. Останні дослідження підвісок автобусів 3 позицій ремонтоздатності проведені досить давно через реструктуризацію автомобільної галузі й стосувались ресорно-пневматичних підвісок автобусів [3,4 ]. Тому актуальним постало питання оцінки ремонтоздатності пневматичних підвісок сучасних вітчизняних автобусів.

Постановка завдання. Метою роботи $є$ порівняльна оцінка алгоритмів демонтажу пневматичної підвіски автобуса А 11110 з позицій доступу під час розбиральних операцій.

Результати дослідження. Досягнення вище означеної мети здійснювалось залученням методу дискретної математики, в якому найбільш повно задачам структурного аналізу складаних одиниць автомобіля відповідає теорія графів [6].

Комплекс розбиральних робіт можна представити графами доступу, у яких вершини означають закінчення робіт, а орієнтовані ребра, зображені відрізками прямих зі стрілками, - послідовність розбиральних робіт. У залежності від конструктивних особливостей складаних одиниць і складових елементів, графи наводять великою гамою усіляких варіантів, що характеризують різні можливості доступу [7].

3 властивостей графа, для зазначених цілей, використовують віддаленість від кореневої вершини графа $d\left(x_{o}, x_{i}\right)$, що визначається як найкоротша відстань і виражається цілими позитивними числами. Чим більша відстань від кореневої вершини графа, тим гірший доступ.

Друга важлива властивість графа — його вага $\mu\left(x_{i}\right)$, яка характеризує кількості складаних одиниць і деталей, зв'язаних з кореневою вершиною, що одночасно знімаються. Чим більша вага вершини графа, тим досконаліша конструкція складаної одиниці (складової частини) 3 позиції ремонтоздатності, тому що при одному роз'єднанні знімається кілька деталей (складаних одиниць), що скорочує витрати праці.

Оцінку досконалості складаної одиниці чи складової частини автотранспортного засобу з умов забезпечення найкращого доступу до деталі, що відмовила, зручніше робити за допомогою функції доступу, що є основним критерієм структурної оцінки ремонтоздатності машин [2]. Функція доступу характеризує пристосованість конструкції до швидкого відновлення втраченої працездатності через заміну невідновлюваного елементу, що вийшов з ладу.

Підвіска керованих коліс (рис. 1а) залежна, пневматична 3 пневматичними пружними елементами рукавного типу, телескопічними гідравлічними амортизаторами. Вона складається 3 передньої осі, двох колісних механізмів-лівого та правого, двох пневматичних рукавних пружних елементів з вмонтованими гумовими обмежувачами ходу стиску, які фіксуються верхньою частиною до кузова. 


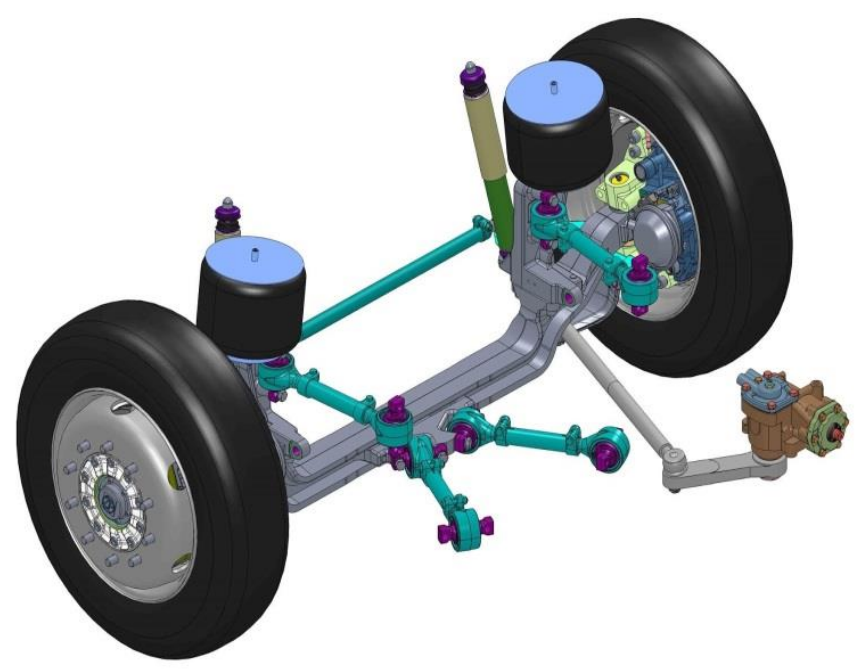

a)

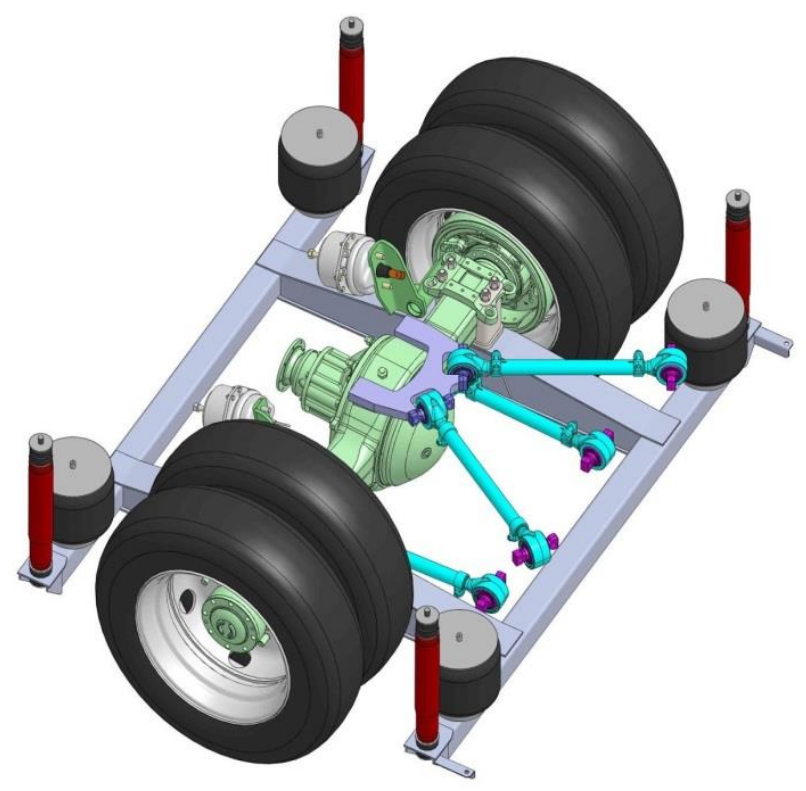

б)

Рис. 1 Загальний вигляд підвісок керованих (а) та ведучих (б) коліс автобуса БАЗ А11110

Підвіска містить два гідравлічні амортизатори двосторонньої дії 3 вмонтованими обмежувачами ходу відбою. Фіксація коліс відносно кузова від повздовжніх та поперечних переміщень здійснюється напрямним пристроєм, що складається 3 двох нижніх важелів: лівого i правого та двох верхніх - лівого та правого. Важелі з'єднуються з кузовом автобуса через гумовометалеві шарніри болтами та гайками. В конструкцію підвіски входить кермова трапеція, яка складається 3 двох важелів, кермових тяг. Вільний доступ $є$ до наступних деталей і складаних одиниць підвіски: до шарнірів верхніх та нижніх важелів підвіски, амортизаторів, пружних рукавних елементів, шарнірів кермових тяг, кронштейнів важелів кермової трапеції, штуцерів приводу гальм. У табл. 1 представлені зведені графи доступу до підвіски керованих коліс автобуса А 11110 за трьох варіантів розбирання. 
Таблиия 1 Графи доступу до пневматичної підвіски керованих коліс автобуса БАЗ А11110 при трьох варіантах розбирання

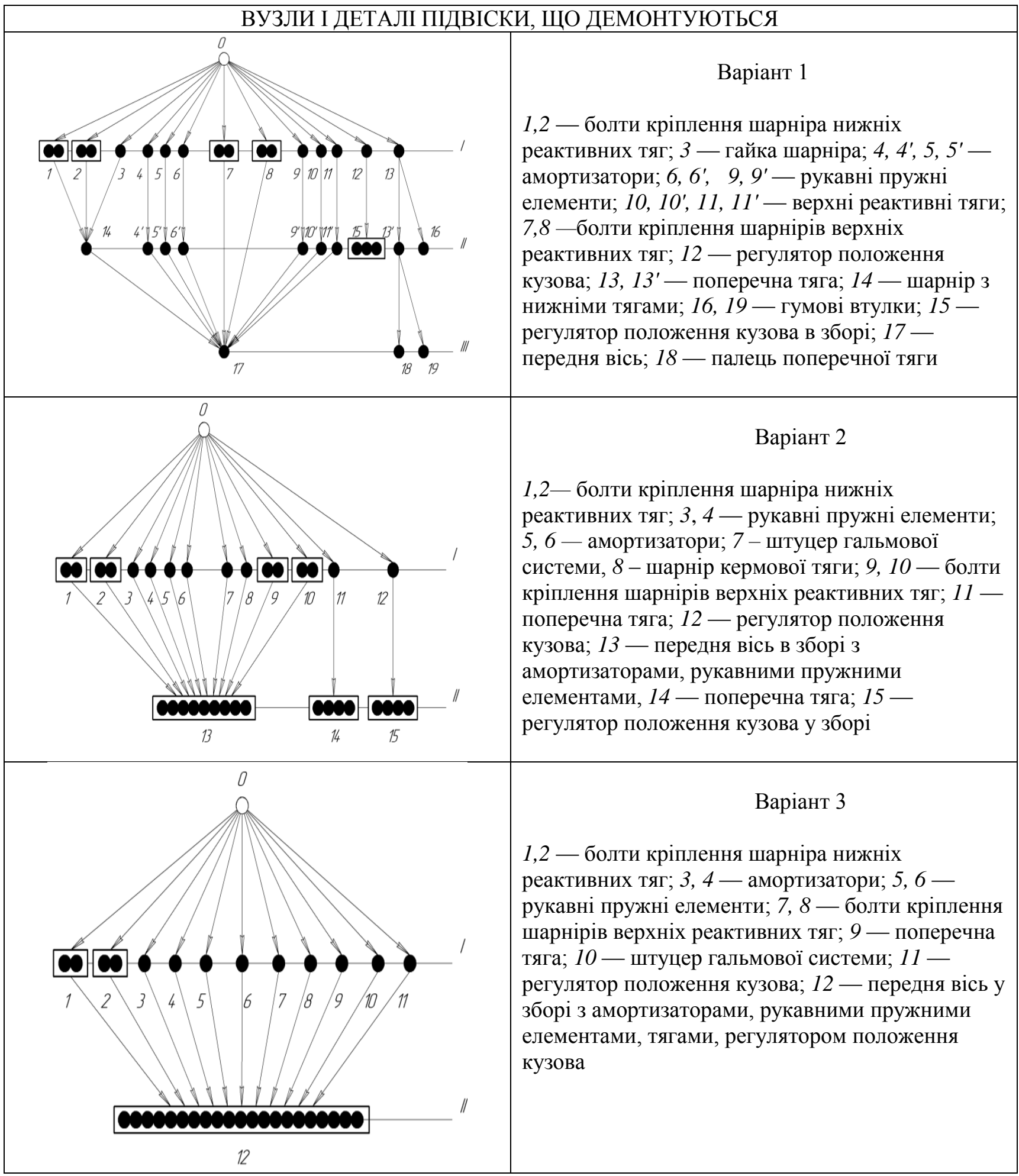


Таблиия 2 Графи доступу до пневматичної підвіски ведучих коліс автобуса БАЗ А11110 при трьох варіантах розбирання

\begin{tabular}{|c|c|}
\hline \multicolumn{2}{|c|}{ ВУЗЛИ І ДЕТАЛІ ПІДВІСКИ, ЩО ДЕМОНТУЮТЬСЯ } \\
\hline 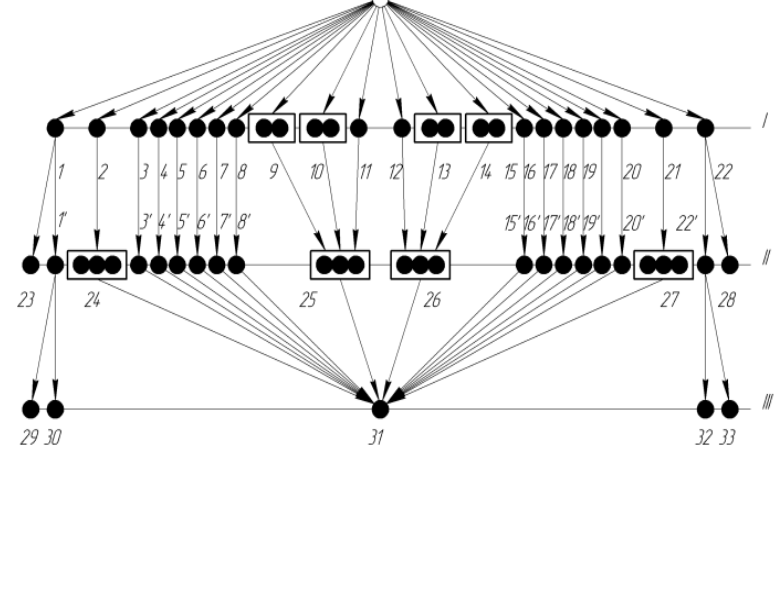 & 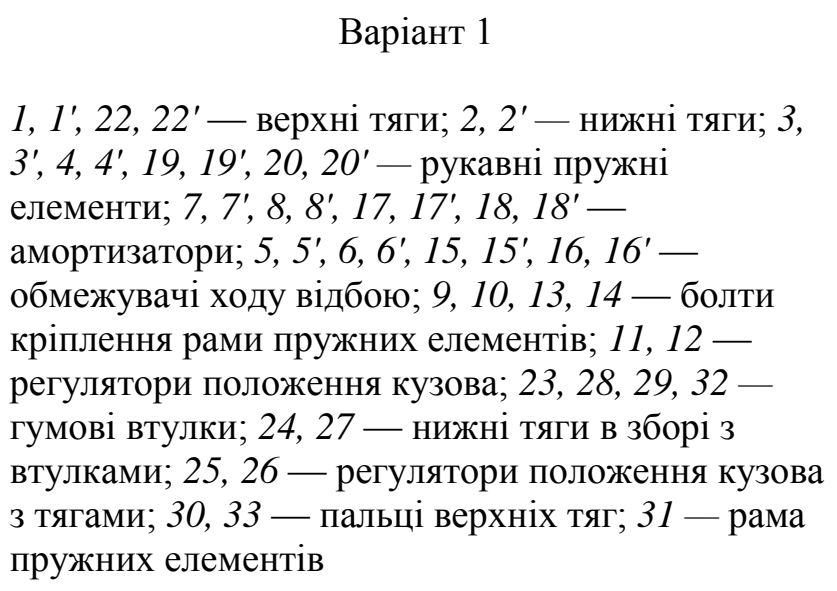 \\
\hline 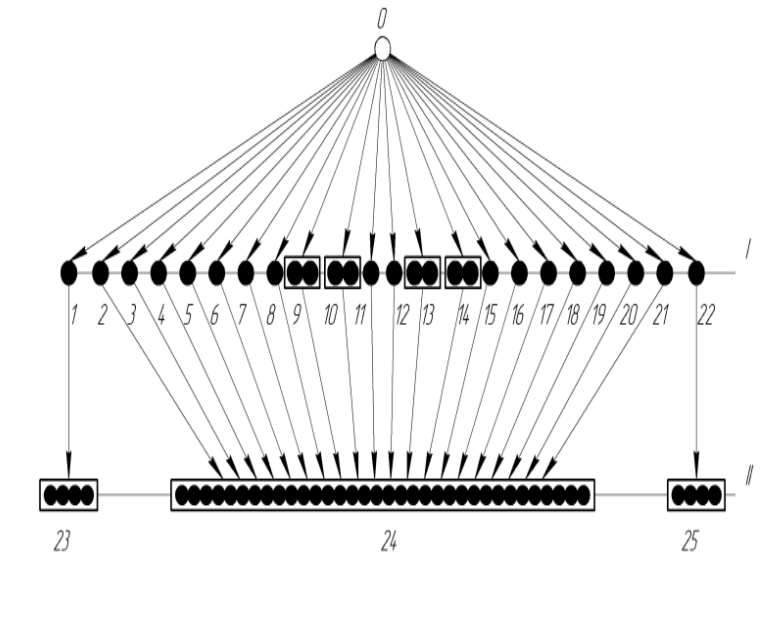 & $\begin{array}{l}\text { Варіант } 2 \\
1,22-\text { верхні тяги; 2, 3, 20, 21- рукавні пружні } \\
\text { елементи; 6, 7, 16, 17- обмежувачі ходу відбою; } \\
\text { 4, 5, 18, 19-амортизатори; 8, 15- нижні тяги; } \\
\text { 9, 10, 13, 14- болтові кріплення рами; } 11,12- \\
\text { регулятори положення кузова; 23, 25- верхні } \\
\text { тяги в зборі з пальцями і гумовими втулками; } 24 \\
\text { - рама пружних елементів у зборі з } \\
\text { амортизаторами, пружними елементами, } \\
\text { обмежувачами відбою, регуляторами положення } \\
\text { кузова з тягами, болтами кріплення рами } \\
\text { пружних елементів }\end{array}$ \\
\hline 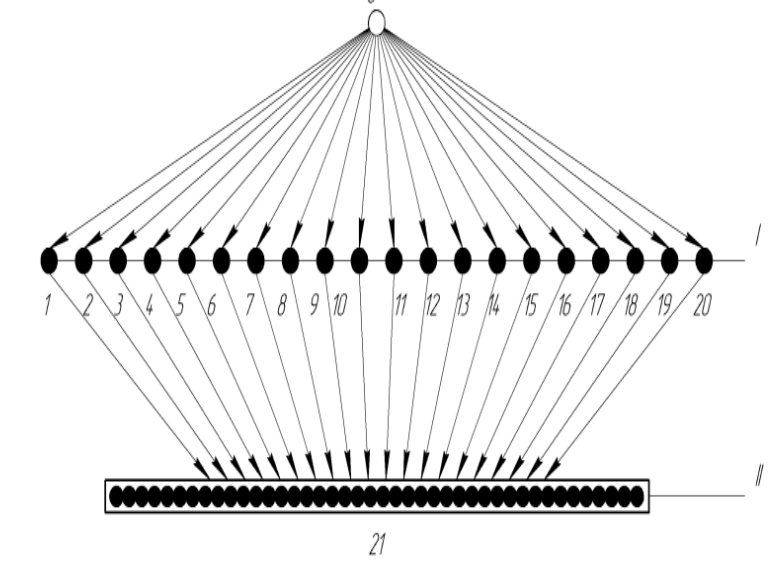 & $\begin{array}{l}\text { Варіант 3 } \\
\text { 1, 2,17,18- амортизатори; 3, 4,15,16- } \\
\text { рукавні пружні елементи; 5, 6, 13,14- } \\
\text { обмежувачі ходу відбою; 7,8- верхні тяги; } 11 \text {, } \\
12 \text { - нижні тяги; 9- фланець ведучого вала; } 10 \\
\text { — штуцер гальмової системи; 19, 20- регулятор } \\
\text { положення кузова; 21- ведучий міст у зборі з } \\
\text { рамою, рукавними пружними елементами, } \\
\text { амортизаторами, обмежувачами ходу відбою, } \\
\text { тягами, пальцями шарнірів, втулками, } \\
\text { регуляторами положення кузова з тягами, } \\
\text { болтами кріплення моста }\end{array}$ \\
\hline
\end{tabular}


(C) Гудз Г.С.,. Глобчак М. В, Коцюмбас О. Й.,Захара І. Я. 2019

Таблиия 3 Результати дослідження ваги і відстані вершин графів доступу до підвіски керованих коліс автобуса БАЗ А11110

\begin{tabular}{|c|c|c|c|c|}
\hline \multirow[b]{2}{*}{$\begin{array}{c}\text { Графи доступу } \\
\text { до деталей, що } \\
\text { відмовили }\end{array}$} & \multicolumn{4}{|c|}{ Характеристика ваги } \\
\hline & Вершини & $\mu\left(x_{i}\right)$ & $F_{\mu}\left(x_{i}\right)$ & $\frac{\mu\left(x_{i}\right) F_{\mu}\left(x_{i}\right)}{\mu^{2}\left(x_{i}\right) F_{\mu}\left(x_{i}\right)}$ \\
\hline \multirow{3}{*}{ Варіант 1} & $\begin{array}{c}3,4,5,6,9,10,11,12,13 \\
14,4^{1}, 5^{1}, 6^{1}, 9^{1}, 11^{1}, \\
13,16,17,18,19\end{array}$ & 1 & 21 & $\begin{array}{l}1 \times 21 \\
1^{2} \times 21\end{array}$ \\
\hline & $1,2,7,8$ & 2 & 4 & $\begin{array}{c}2 \times 4 \\
2^{2} \times 4\end{array}$ \\
\hline & 15 & 3 & 1 & $\begin{array}{c}3 \times 1 \\
3^{2} \times 1 \\
\end{array}$ \\
\hline \multirow{4}{*}{ Варіант 2} & $3,4,5,6,7,8,11,12$ & 1 & 8 & $\begin{array}{l}1 \times 8 \\
1^{2} \times 8\end{array}$ \\
\hline & 9,10 & 2 & 4 & $\begin{array}{l}2 \times 4 \\
2^{2} \times 4 \\
\end{array}$ \\
\hline & 14,15 & 4 & 2 & $\begin{array}{l}4 \times 2 \\
4^{2} \times 2\end{array}$ \\
\hline & 13 & 9 & 1 & $\begin{array}{l}9 \times 1 \\
9^{2} \times 1 \\
\end{array}$ \\
\hline \multirow{3}{*}{ Варіант 3} & $\begin{array}{c}3,4,5,6,7,8,9,10, \\
11\end{array}$ & 1 & 9 & $\begin{array}{r}1 \times 9 \\
1^{2} \times 9 \\
\end{array}$ \\
\hline & 1,2 & 2 & 2 & $\begin{array}{l}2 \times 1 \\
2^{2} \times 1\end{array}$ \\
\hline & 12 & 21 & 1 & $\begin{array}{l}21 \times 1 \\
21^{2} \times 1\end{array}$ \\
\hline \multirow[b]{2}{*}{$\begin{array}{l}\text { Графи доступу } \\
\text { до деталей, що } \\
\text { відмовили }\end{array}$} & \multicolumn{4}{|c|}{ Характеристика відстаней } \\
\hline & Вершини & $d\left(x_{0} x_{1}\right)$ & $F_{d}\left(x_{0} x_{1}\right)$ & $\frac{d\left(x_{0} \cdot x_{1}\right) F_{d}\left(x_{0} \cdot x_{1}\right)}{d^{2}\left(x_{0} \cdot x_{1}\right) F_{d}\left(x_{0} \cdot x_{1}\right)}$ \\
\hline \multirow{3}{*}{ Варіант 1} & $\begin{array}{c}1,2,3,4 ; 5,6,7,8 \\
9,10,11,12,13 \\
\end{array}$ & 1 & 13 & $\begin{array}{r}1 \times 13 \\
1^{2} \times 13 \\
\end{array}$ \\
\hline & $\begin{array}{c}14,4^{1}, 5^{1}, 6^{1}, 9^{1}, 10^{1} \\
11,15,13^{1}, 16\end{array}$ & 2 & 10 & $\begin{array}{r}2 \times 10 \\
2^{2} \times 10 \\
\end{array}$ \\
\hline & $17,18,19$ & 3 & 3 & $\begin{array}{r}3 \times 3 \\
3^{2} \times 3 \\
\end{array}$ \\
\hline \multirow[t]{2}{*}{ Варіант 2} & $\begin{array}{c}1,2,3,4,5,6,7,7 \\
8,9,10,11\end{array}$ & 1 & 11 & $\begin{array}{l}1 \times 11 \\
1^{2} \times 11\end{array}$ \\
\hline & 12 & 2 & 1 & $\begin{array}{l}2 \times 1 \\
2^{2} \times 1\end{array}$ \\
\hline \multirow{2}{*}{ Варіант 3} & $\begin{array}{c}1,2,3,4,5,6,7,7 \\
8,9,10,11\end{array}$ & 1 & 11 & $\begin{array}{l}1 \times 11 \\
1^{2} \times 11\end{array}$ \\
\hline & 12 & 2 & 1 & $\begin{array}{c}2 \times 1 \\
2^{2} \times 1\end{array}$ \\
\hline
\end{tabular}


Таблиия 4 Результати дослідження ваги і відстані вершин графів доступу до підвіски ведучих коліс автобуса БАЗ А11110

\begin{tabular}{|c|c|c|c|c|}
\hline \multirow{2}{*}{$\begin{array}{c}\text { Графи доступу } \\
\text { до деталей, що } \\
\text { відмовили }\end{array}$} & \multicolumn{4}{|c|}{ Характеристика ваги } \\
\hline & Вершини & $\mu\left(x_{i}\right)$ & $F_{\mu}\left(x_{i}\right)$ & $\frac{\mu\left(x_{i}\right) F_{\mu}\left(x_{i}\right)}{\mu^{2}\left(x_{i}\right) F_{\mu}\left(x_{i}\right)}$ \\
\hline \multirow[t]{3}{*}{ Варіант 1} & $\begin{array}{c}1,2,3,4,5,6,7,8,9,10,11,12, \\
15,16,17,18,19,20,21,22, \\
23,1^{1}, 3^{1}, 4^{1}, 5^{1}, 6^{1}, 7^{1}, 8^{1}, 15 \\
16^{1}, 17^{1}, 18^{1}, 19^{1}, 20^{1}, 22, \\
28,29,30,31,32,33\end{array}$ & 1 & 39 & $\begin{array}{r}1 \times 39 \\
1^{2} \times 39\end{array}$ \\
\hline & $9,10,13,14$ & 2 & 4 & $\begin{array}{l}2 \times 4 \\
2^{2} \times 4\end{array}$ \\
\hline & $24,25,26,27$ & 3 & 4 & $\begin{array}{l}3 \times 4 \\
3^{2} \times 4\end{array}$ \\
\hline \multirow{4}{*}{ Варіант 2} & $\begin{array}{c}1,2,3,4,5,6,7,8,11,12,15 \\
16,17,18,19,20,21,22\end{array}$ & 1 & 18 & $\begin{array}{l}1 \times 18 \\
1^{2} \times 18\end{array}$ \\
\hline & $9,10,13,14$ & 2 & 4 & $\begin{array}{c}2 \times 4 \\
2{ }^{4} \times 4\end{array}$ \\
\hline & 23,25 & 4 & 2 & $\begin{array}{l}4 \times 2 \\
4^{2} \times 2 \\
\end{array}$ \\
\hline & 24 & 34 & 1 & $\begin{array}{l}34 \times 1 \\
34^{2} \times 1\end{array}$ \\
\hline \multirow[t]{2}{*}{ Варіант 3} & $\begin{array}{c}1,2,3,4,5,6,7,8,9,10,11 \\
12,13,14,15,16,17 \\
18,19,20\end{array}$ & 1 & 20 & $\begin{array}{l}1 \times 20 \\
1^{2} \times 20\end{array}$ \\
\hline & 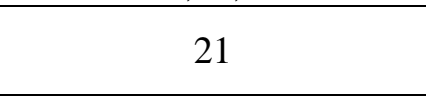 & 42 & 1 & $\begin{array}{c}42 \times 1 \\
42^{2} \times 1\end{array}$ \\
\hline \multirow{2}{*}{$\begin{array}{c}\text { Графи доступу } \\
\text { до деталей, що } \\
\text { відмовили }\end{array}$} & \multicolumn{4}{|c|}{ Характеристика відстаней } \\
\hline & Вершини & $d\left(x_{0} x_{1}\right)$ & $F_{d}\left(x_{0} x_{1}\right)$ & $\frac{d\left(x_{0} \cdot x_{1}\right) F_{d}\left(x_{0} \cdot x_{1}\right)}{d^{2}\left(x_{0} \cdot x_{1}\right) F_{d}\left(x_{0} \cdot x_{1}\right)}$ \\
\hline \multirow{3}{*}{ Варіант 1} & $\begin{array}{c}1,2,3,4,5,6,7,8,9,10,11 \\
12,13,14,15,16,17,18 \\
19,20,21,22\end{array}$ & 1 & 22 & $\begin{array}{l}1 \times 22 \\
1^{2} \times 22\end{array}$ \\
\hline & $\begin{array}{c}23,1^{1}, 24,3^{1}, 4^{1}, 5^{1}, 6^{1}, 7^{1} \\
8^{1}, 25,26,15^{1}, 16^{1}, 17^{1}, 18^{1} \\
19^{1}, 20^{1}, 27,22^{1}, 28,\end{array}$ & 2 & 20 & $\begin{array}{l}2 \times 20 \\
2^{2} \times 20\end{array}$ \\
\hline & $29,30,31,32,33$ & 3 & 5 & $\begin{array}{r}3 \times 5 \\
3^{2} \times 5 \\
\end{array}$ \\
\hline \multirow[t]{2}{*}{ Варіант 2} & $\begin{array}{c}1,2,3,4,5,6,7,8,9,10, \\
11,12,13,14,15,16, \\
17,18,19,20,21,22\end{array}$ & 1 & 22 & $\begin{array}{l}1 \times 22 \\
1^{2} \times 22\end{array}$ \\
\hline & $23,24,25$ & 2 & 3 & $\begin{array}{r}2 \times 3 \\
2^{3} \times 3 \\
\end{array}$ \\
\hline \multirow[t]{2}{*}{ Варіант 3} & $\begin{array}{c}1,2,3,4,5,6,7,8,9,10,11 \\
12,13,14,15,16,17 \\
18,19,20 \\
\end{array}$ & 1 & 20 & $\begin{array}{l}1 \times 20 \\
1^{2} \times 20\end{array}$ \\
\hline & 21 & 2 & 1 & $\begin{array}{l}2 \times 1 \\
2^{2} \times 1\end{array}$ \\
\hline
\end{tabular}


Визначимо якісну оцінку досконалості конструкції з точки зору пристосованості до швидкого відновлення - функції доступу. Для цього визначимо кількість вершин з різною вагою і віддаллю, рівним 1, 2, 3. Дані про вагу і віддалі підвіски керованих коліс автобуса БАЗ А11110 наведені у табл. 3, а для підвіски ведучих коліс - у табл. 4.

Згідно [3] функція доступу визначається за формулою:

$$
\Delta \varphi=\varphi \cdot d\left(x_{0} \cdot x_{1}\right)-\varphi_{\mu}\left(x_{1}\right),
$$

де $\varphi \cdot d\left(x_{0} \cdot x_{1}\right)=d^{2}\left(x_{0} \cdot x_{1}\right) \cdot F d\left(x_{0} \cdot x_{1}\right)-\left[d\left(x_{0} \cdot x_{1}\right) \cdot F d\left(x_{0} \cdot x_{1}\right)\right]^{2}$;

$$
\varphi_{\mu}\left(x_{1}\right)=\mu^{2}\left(x_{1}\right) F_{\mu}\left(x_{1}\right)-\left[\mu\left(x_{1}\right) F_{\mu}\left(x_{1}\right)\right]^{2} \text {. }
$$

Для прикладу здійснимо визначення функції доступу для першого варіанту розбирання передньої підвіски автобуса БАЗ А11110 за даними табл. 3.

$$
\begin{aligned}
& \varphi \cdot d\left(x_{0} \cdot x_{1}\right)=d^{2}\left(x_{0} \cdot x_{1}\right) \cdot F d\left(x_{0} \cdot x_{1}\right)-\left[d\left(x_{0} \cdot x_{1}\right) \cdot F d\left(x_{0} \cdot x_{1}\right)\right]^{2}= \\
& =\left(1^{2} \cdot 13+2^{2} \cdot 10+3^{2} \cdot 3\right)-(1 \cdot 13+2 \cdot 10+3 \cdot 3)^{2}=-1684 \\
& \varphi_{\mu}\left(x_{1}\right)=\mu^{2}\left(x_{1}\right) F_{\mu}\left(x_{1}\right)-\left[\mu\left(x_{1}\right) F_{\mu}\left(x_{1}\right)\right]^{2}=\left(1^{2} \cdot 21+2^{2} \cdot 4+3^{2} \cdot 1\right)- \\
& -(1 \cdot 21+2 \cdot 4+3 \cdot 1)^{2}=-978 \\
& \Delta \varphi=\varphi \cdot d\left(x_{0} \cdot x_{1}\right)-\varphi_{\mu}\left(x_{1}\right)=-1684-(-978)=-706 .
\end{aligned}
$$

Аналогічно визначимо функції доступу для всіх трьох варіантів розбирання підвісок керованих і ведучих коліс автобуса БАЗ А11110, зведемо їх у табл. 5 і проведемо аналіз з метою отримання практичних рекомендацій.

Таблиия 5 Результати визначення функцій доступу

\begin{tabular}{|c|c|c|c|c|}
\hline \multirow{2}{*}{ Об'єкт } & Варіант & $\varphi \cdot d\left(x_{0} \cdot x_{1}\right)$ & $\varphi_{\mu}\left(x_{1}\right)$ & $\Delta \varphi$ \\
\hline Підвіска & I & -1684 & -978 & -706 \\
\cline { 2 - 5 } керованих коліс & II & $\mathbf{- 3 0 0}$ & $\mathbf{- 1 2 3 2}$ & $\mathbf{+ 9 3 2}$ \\
\cline { 2 - 5 } автобуса & III & -154 & -698 & +544 \\
БАЗ А11110 & & & -3390 & -2392 \\
\hline Підвіска & I & -5782 & $\mathbf{- 4 5 2 4}$ & $\mathbf{+ 3 8 7 4}$ \\
\cline { 2 - 5 } ведучих коліс & II & $\mathbf{- 7 5 0}$ & -2060 & +1600 \\
автобуса \\
БАЗ А11110
\end{tabular}

За результатами розрахунків значень функцій доступу (див. табл. 5) найбільш раціональним для розбирання пневматичної підвіски як керованих, так й ведучих коліс автобуса $є$ другий варіант.

Висновок. За допомогою структурного аналізу можна провести порівняльну оцінку раціональної технології розбирання не лише підвісок, а й різних вузлів, агрегатів та систем автотранспортних засобів з позицій доступу.

1. Полянський О. С. Технологія відновлення деталей та ремонту автомобілів / О. С. Полянський, Б. В. Савченков, С. О. Дубінін.-Харків: Вид-во ХНАДУ, 2012.-312 с.

2. Ремонтопригодность машин/под. ред. П. Н. Волкова.-М.: Машиностроение, 1975.-368 с.

3. Гудз Г. С. Структурная оценка ремонтопригодности подвески автобуса ЛАЗ-4202/Г. С. Гудз, Ю. И. Дробот,П. И. Еременко.-Львов: Труды ВКЭИАВТОБУСПРОМ, 1981.-С. 187-195.

4. Кельман I. І. Підвищення експлуатаційних властивостей автобуса в сучасних умовах /I. I. Кельман, К. Лейда, Р. А. Акопян.-Львів: НВП «Мета», 1997.-253 с.

5. Гудз Г. С. Визначення ремонтоздатності пневматичних підвісок автобуса з позицій доступу/ Г. С. Гудз, М. В. Глобчак, О. Й. Коцюмбас, М. М. Осташук. - Харьков, Сб. н. тр. «Автомобильный транспорт». ХНАДУ, вып. 43.-С. 47-53.

6. Зиков О. О. Основы теории графов/О. О. Зиков.-М.: Вузовская книга, 2004.-664 с.

7. Иващенко Н. И. Технология ремонта автомобилей/Н. И. Иващенко.- К.: Вища школа, 1977.-360 с.

\section{REFERENCES}

1. Polanskyi O. S. Technolohia widnowlennai detalei ta remontu avtomobiliv/O.S. Polanskyi, B.V. Savchenkov, E. O. Dubinin.- Xarkiv^^ Vyd-vo XNDTU, 2012.-312 s. p.

2. Remontoprihodnost mashyn/ pod. red. P. N. Volkova-M.: Mashynostrojenie, 1975.- $368 \mathrm{~s} /$

3. Structurnaj ozenka remontoprihodnosti podveski avtobusa LAS-4202/G. S. Hudz, Yu. I. Drobot, P. I. EremenkoLviv:Trudy VKEIAVTOBUSPROM, 1981.- S. 187-195.

4. Kelman I. I. Pidvyshennja ekspluataziynyx vlastyvostej avtobusa v suchasnyx umovax/Improvement of the operational properties of the bus in modern conditions / I. I. Kellman, K. Leida, R. A. Akopajn, Lviv: NVP "Meta", 1997.-253 s.

5. Hudz G.S. Vysnachennja remontoprihodnosti pnevmatychnyx pidvisok avtobusa s posyziu dostupu/ G.S. Hudz, M.V. Hlobchak, O.Y Kotsjumbas, M. M. Ostashuk. - Kharkiv, Sb. n. pr "Avtomodilnyi transport". HNADU, vyp. 43.- S. 47-53.

6. Zykov O. O.Osnovy teoriy hrafov / O. O. Zykov-M .: Vuzovsraj knyha, 2004.-664 s. 
G. Hudz, M. Hlobchak, O. Kotsjumbas, I. Zachara. Comparative evaluation of bus A11110 pneumatic suspension dismanteling alcorithms on the basis of structural analysis/

Air suspensions of buses' steered and driving wheels consist of a big amount of parts and elements with directed connections between them. The evaluation of perfection of these connections can be performed with the help of graph theory, which take into considerations different methods for realization of ordered interrelations in the access graph. In the former the vertices denote the ends of the jobs, its edges, depicted as intercepts with arrows, describe the sequence of the disassembling jobs.

Depending of the suspension's construction, those graphs illustrate different variants, which characterize different possibilities of access.

For mentioned purposes, among the graph's properties the distance from the root vertice is used, which is defined as the shortest path and denoted as a whole positive number.

The greater the distance, the worse the access is. The another important property of graph is its weight, which characterize amount of assembled units and parts, connected with the root vertice, which can be detached simultaneously. The bigger the weight of root vertice is, the more perfect design of composed unit (composing part) is from the maintainability point of view, - using one disconnection several parts (composed units) can be detached, which economize on labor costs.

Evaluation of composed units or composing parts' perfectness of automotive vehicle from point of view of the best access to the faulted part is the best performed with the help of access function, which is the main criteria of structural analysis of machine's maintainability. Access function characterizes suitability of given machine's design for rapid recovery from lost functionability through the change of the non-renewable fault element.

That is why in this article the design features of air suspensions of ruled and driving wheels of A11110 bus are described, their three-level access graphs are mapped and access functions for three options of disassembling works are calculated. Quantative analysis of access functions has shown that the most rational option for disassembling of bus' suspensions is the second one. Proposed method of structural analysis of bus's suspension maintainability can be applied for other parts of automotive vehicles.

Key words: pneumatic suspension, bus, maintainability, access, graphs and functions.

\section{АВТОРИ:}

ГУДЗ Густав Степанович, доктор технічних наук, професор кафедри експлуатації та ремонту автомобільної техніки, Національний університет «Львівська політехніка».

ГЛОБЧАК Михайло Васильович, кандидат технічних наук, доцент, доцент кафедри експлуатації та ремонту автомобільної техніки, Національний університет «Львівська політехніка» е-mail: mykhailo.v.hlobchak@lpnu.ua.

КОЦЮМБАС Олег Йосифович, кандидат технічних наук, старший викладач кафедри експлуатації та ремонту автомобільної техніки, Національний університет «Львівська політехніка».

ЗАХАРА Ігор Ярославович, кандидат технічних наук, доцент кафедри автомобільного транспорту, Івано-Франківський національний технічний університет нафти і газу.

АВТОРЫ:

ГУДЗ Густав Степанович, доктор технических наук, профессор кафедры эксплуатации ти ремонта автомобильной техники, Национальный университет «Львовская политехника».

ГЛОБЧАК Михаил Васильевич, кандидат технических наук, доцент, доцент кафедры эксплуатации и ремонта автомобильной техники, Национальный университет «Львовская политехника». e-mail: mykhailo.v.hlobchak@lpnu.ua.

КОЦЮМБАС Олег Йосифович, кандидат технических наук, старший преподаватель кафедры эксплуатации и ремонта автомобильной техники, Национальный университет «Львовская политехника».

ЗАХАРА Ігор Ярославович, кандидат технических наук, доцент, кафедры автомобильного транспорта, Ивано-Франковский национальный технический университет нефты и газа.

\section{AUTHORS:}

Gustav Hudz, Doctor of Technical Sciences, Professor of Department of Operation and Repair of Motor Vehicles, National Technical University «Lviv Polytechnic».

Mykhailo Hlobchak, PhD in Engeneering, Professor of Department of Operation and Repair of Motor Vehicles, National Technical University «Lviv Polytechnic». E-mail: mykhailo.y.hlobchak@lpnu.ua

Oleh Kotsumbas, $\mathrm{PhD}$ in Engeneering, Senior Lecturer of Professor of Department of Operation and Repair of Motor Vehicles, National Technical University «Lviv Polytechnic».

Ihor Zachara, PhD in Engeneering, Associate Professor of Department of Automobile Transport, Ivano-Frankivsk National Technical University. 